\title{
The economics of early retirement
}

Received: 27th March, 2001

\section{Tryggvi Thor Herbertsson}

holds a degree in Industrial Administration from the Technical College of Iceland, an MSc in economics from the University of Iceland, and a PhD in economics from the University of Aarhus.

Herbertsson is an associate professor at the Faculty of Economics, is the Director of the Institute of Economic Studies at the University of Iceland, and is a research associate at the Centre for Pensions and Social Insurance at Birkbeck College, University of London. His main research fields are pensions and social security, economic growth, and the macroeconomics of natural resources. Herbertsson has published extensively in academic journals and books, written newspaper articles and reports, edited books, and is the author of the book 'Sources of Economic Growth'.

He has been a consultant to private companies, institutions, and international organisations as well as the governments of Denmark, Finland, the Faroe Islands, Iceland, Norway, Sweden, and Uganda.

\begin{abstract}
The trend in most of the industrialised countries is in the direction of decreasing labour force participation of older workers. The steady withdrawal of workers from the workforce at a younger age suggests that retirement income is gradually increasing and/or that older workers are increasingly being forced out of the labour market. Regardless of whether early retirement can be traced to the labour supply or the labour demand side of the labour market, it constitutes a withdrawal of resources from production, a lowered tax base, and an increased burden on pension and fiscal systems. This paper identifies and discusses alternative theories on why people retire early.
\end{abstract}

Keywords: early retirement; labour supply/demand; foregone output

Tryggvi Thor Herbertsson IoES, University of Iceland, Aragata 14, 101 Reykjavik, Iceland

Tel: +354 535 4535; Fax: +354 525 4096; e-mail: tthh@hi.is

\section{Introduction}

The trend in most of the industrialised countries is in the direction of decreasing labour market participation of older workers. The steady withdrawal of workers from the workforce at a younger age suggests that retirement income is gradually increasing and/or that older workers are increasingly being forced out of the labour market. Consequently, the huge increases in early retirement in industrialised countries in the last century can be explained by a labour supply decision of workers on the one hand and by labour demand decisions of employers on the other, (as well as changing demographic realities).

Unlike his eighteenth century colleague, the average worker today has accumulated substantial wealth during his working life. Moreover, incentives built into national social insurance systems often encourage him to retire early. The modern worker can not only afford to retire early, but is also willing to do so since recreational opportunities have increased and relative prices of leisure activities have decreased.

Although private wealth has increased and public retirement systems have advanced, not all workers retire voluntarily. The UK Cabinet Office ${ }^{1}$ finds that, at most, one-third of early retirees in the age group between 50 and the official state pension retirement age in the UK retire voluntarily, and that only about 12 per cent have made plans for retirement (see Table 1). 


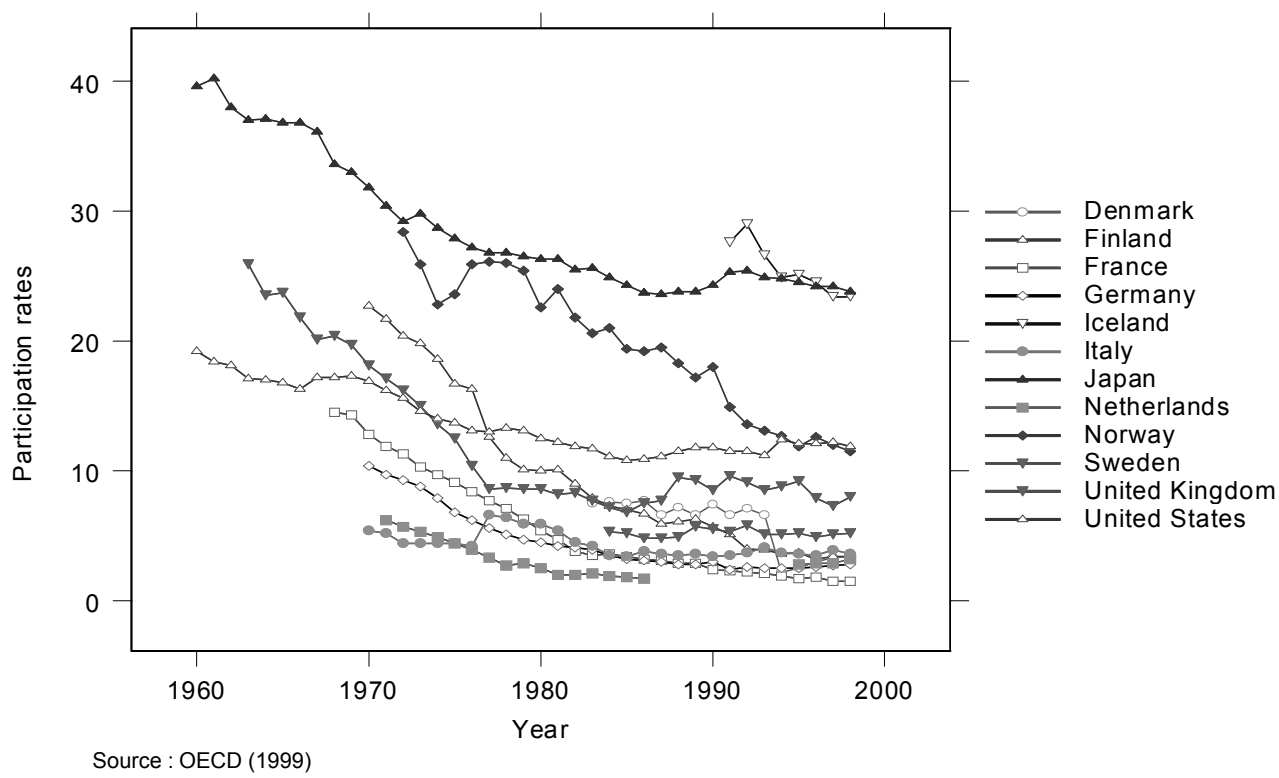

Figure 1: Labour force participation rates for men over 65 in the OECD

Regardless of whether early retirement can be traced to the labour supply or the labour demand side of the labour market, it constitutes a withdrawal of resources from production, a lowered tax base, and an increased burden on pension and fiscal systems.

In order to assess the costs associated with early retirement, Herbertsson and Orzsag $^{2}$ have developed a measure of unused production capacity, which captures the economic costs arising from early

Table 1: Labour force status of inactive people between age 50 and state pension age in the UK

\begin{tabular}{ll} 
& \% of total \\
\hline Voluntary inactive & $\mathbf{3 2}$ \\
Retired & 18 \\
Looking after family & 14 \\
Involuntary inactive & $\mathbf{5 4}$ \\
Long-term sick or disabled & 44 \\
Looking for work & 10 \\
Other reasons for inactiveness & $\mathbf{1 5}$ \\
Do not need job & 5 \\
Other & 10 \\
\hline
\end{tabular}

Source: UK Cabinet Office ${ }^{1}$ retirement in terms of forgone economic output.

\section{Costs of early retirement}

In 17 OECD countries, for which data are available, the proportion of the 55-64 age cohort of employed males fell by an average of more than 10 percentage points between 1980 and 1996. ${ }^{3}$

Similarly, as illustrated in Figure 1, labour force participation rates for those of 65 and above have fallen significantly across all the economies in question. ${ }^{4}$

The withdrawal of older workers from the labour force creates a variety of economic challenges, including an increase in unused production capacity. Herbertsson and Orszag ${ }^{2}$ develop a simple framework, which incorporates simple general equilibrium effects, to assess the cost of early retirement of 55-64-year-olds in the OECD. Table 2 shows the fraction of output lost in the countries in the period 1979-98.

The calculations correct for business 
Table 2: Costs of early retirement in OECD countries as a share of potential GDP

\begin{tabular}{llll} 
& $\begin{array}{l}1980 \\
\%\end{array}$ & $\begin{array}{l}\mathbf{1 9 9 0} \\
\%\end{array}$ & $\begin{array}{l}\mathbf{1 9 9 8} \\
\%\end{array}$ \\
\hline Hungary & - & - & 15.9 \\
Belgium & - & 15.2 & 13.5 \\
Luxemburg & - & 12.5 & 13 \\
Austria & - & - & 12.3 \\
Germany & 7.7 & 9.5 & 10.9 \\
Greece & - & 10.4 & 10.5 \\
Czech Republic & - & - & 10.5 \\
France & 6.2 & 11.2 & 10.5 \\
Netherlands & 8.1 & 10.5 & 10.1 \\
Poland & - & - & 10.1 \\
Finland & 8.2 & 9.6 & 9.7 \\
Spain & 4.8 & 9.7 & 9.2 \\
Portugal & 6.0 & 9.1 & 7.7 \\
Denmark & - & 6.9 & 7.7 \\
UK & - & 7.5 & 7.6 \\
Ireland & - & 6.9 & 7.4 \\
Austria & 7.5 & 7.5 & 6.9 \\
Canada & 5.5 & 6.7 & 6.7 \\
Sweden & 5.9 & 4.7 & 4.8 \\
USA & 5.8 & 5.4 & 4.7 \\
New Zealand & - & 7.9 & 4.7 \\
Turkey & - & 5.0 & 4.2 \\
Japan & 2.9 & 4.3 & 4.2 \\
Norway & 5.0 & 4.9 & 3.9 \\
Switzerland & - & - & 2.9 \\
Korea & - & 2.2 & 2.7 \\
Mexico & - & - & 2.6 \\
Iceland & - & - & 0.5 \\
OECD average & $\mathbf{5 . 8}$ & $\mathbf{6 . 7}$ & $\mathbf{6 . 3}$ \\
\hline
\end{tabular}

Source: Herbertsson and Orszag ${ }^{5}$

cycles by using the relative labour participation of older workers (55-64 year-olds) and younger workers (25-54 year-olds) as a benchmark. The total output gap due to a lack of full labour force utilisation is considerably higher, as indeed was noted by Gruber and Wise. ${ }^{5}$ The analysis suggests a cost estimate of early retirement of 5-7 per cent of potential annually in the OECD, with higher figures in the EU. The exercise is not very sensitive to reasonable variations in assumptions. This cost rose rapidly after the 1970s in the OECD, peaked in the mid-1980s, and has declined since, although it is still not at the 1970s level.

Although some of the decline in labour market participation is a common trend across the OECD countries, there remain substantial differences across the countries with regard to the level of labour market participation and its rate of decline. Continental and Eastern Europe tend to have higher costs than the rest of the OECD, but Iceland has particularly low costs.

These differences are important for policy makers to the extent that their causes are rooted in economic policy and structure rather than in cultural and environmental factors. However, identifying causal relationships is difficult because, in many countries, early retirement schemes were expanded in the 1980 s as a way of reducing high youth unemployment. It is therefore difficult to discern whether the increase in early retirement resulted from the early retirement schemes that were in place, or were simply an indirect consequence of macroeconomic factors generating the high levels of unemployment. Indeed, one of the key themes here is the examination of labour demand as well as labour supply in policy assessment. ${ }^{6}$

While the calculations above measure the cost of early retirement and the potential gains from successful reforms, they do not suggest specific reforms. The micromodelling of the gains from specific reforms is clearly beyond the scope of this paper. However, in light of the costs associated with early retirement, it is useful to summarise alternative theories on why people retire early.

\section{Labour supply}

The body of research on early retirement has focused on the supply side of the labour market and incentives thereof. Incentives such as wealth, accrual rates, earnings tests, taxes, and so on, play a crucial role in determining labour supply of older workers. Boskin ${ }^{7}$ was one of the first to pay close attention to the effects of incentives on early retirement. Other 
subsequent work includes Quinn et al. ${ }^{8}$ Indeed, incentives are the focus of a huge body of US literature that includes papers by Stock and Wise ${ }^{9}$ and Fields and Mitchell. ${ }^{10}$ Empirical work in Europe has also examined early retirement from an incentive-based approach; examples include Borsch-Supan ${ }^{11}$ for Germany, and Meghir and Whitehouse ${ }^{12}$ for the UK.

There are a number of comprehensive studies on incentives and early retirement. These include work by the OECD,${ }^{13,14}$ which focuses on incentives created on both the supply and the demand side of the labour market, an EU project published on the European Economy, and a NBER book edited by Gruber and Wise. ${ }^{5}$ The methodology in each of these cases was slightly different. The EU study focuses on replacement rates for different routes out of the labour market, whereas the Gruber \& Wise project highlights the concept of pension wealth or accumulated pension assets. The Gruber \& Wise approach is notable because it includes comparisons across a large number of countries using the same methodology. It has spurred much policy and academic interest in its findings. However, the Gruber \& Wise study offers only limited insight into the pension systems of the countries in question because it did not incorporate the general impact of private benefits. It is important to examine private benefits, particularly individual accounts with tax advantages, when considering incentives for early retirement, especially since individual accounts are sometimes used to fund early retirement.

\section{Replacement rates}

While the studies mentioned above accurately characterise the incentive issues and the structure of early retirement benefits, causal explanation is lacking. It is generally difficult to find evidence that can link microeconomic labour supply response to the incentives in question, and it may well be that weak incentives to continue working are a policy response to labour demand shocks. For example Blöndahl and Scarpetta ${ }^{15}$ find no clear relationship between high replacement rates and early retirement.

Johnson, ${ }^{16}$ however, has had greater success in his findings. He reports that historical data from 13 industrialised countries show a rapid fall in labour force participation of male workers aged 60-64 after pensions were extended to them. Johnson estimates the participation elasticity to be -0.06 with respect to replacement rates - the average pension benefits of couples/average wages of male ratio - and 0.19 to the net-of-tax wage. Furthermore, he estimates that the growth of old-age insurance explains about 11 per cent of the reduction in labour force participation of males aged 60-64 since 1920, and he concludes by stating that greater private wealth probably explains most of the remainder.

\section{Wealth}

Costa $^{17}$ reports that higher private wealth, such as increased home ownership, is the major explanation for the long downward trend in labour force participation of older-age male workers. Increased female labour force participation might contribute to more widespread early retirement of males, as higher female participation adds to household wealth. Costas surveys a number of studies on early retirement in the USA and reports an elasticity of labour force non-participation with respect to income (wealth) from disability, old age and survivors' pensions and assets. His conclusion is that the effect from a dollar in private pension on retirement is very different from a dollar 
Table 3: Generosity indicators of non-employment benefits for older workers and male unemployment in Europe in 1995, ordered by elderly unemployment

\begin{tabular}{lllll}
\hline & $\begin{array}{l}\text { Disability } \\
\text { schemes } \\
\%\end{array}$ & $\begin{array}{l}\text { Unemployment } \\
\text { schemes } \\
\%\end{array}$ & $\begin{array}{l}\text { Unemployment } \\
\text { Male total } \\
\%\end{array}$ & $\begin{array}{l}\text { Unemployment } \\
\text { male 55-64 } \\
\%\end{array}$ \\
\hline Luxemburg & 52.9 & 77.6 & 2.1 & 0.0 \\
Switzerland & 43.4 & 10.7 & 4.1 & 2.0 \\
Netherlands & 70.0 & 52.5 & 5.8 & 2.6 \\
Norway & 57.0 & 17.2 & 5.1 & 4.2 \\
Iceland & 39.0 & 41.9 & 4.8 & 4.3 \\
Austria & 68.1 & 48.9 & 4.9 & 4.4 \\
Italy & 36.0 & 50.0 & 9.3 & 4.5 \\
Portugal & 71.7 & 61.6 & 6.6 & 5.0 \\
Sweden & 69.6 & 14.4 & 8.3 & 5.5 \\
Denmark & 38.8 & 71.5 & 5.6 & 7.3 \\
Belgium & 29.2 & 20.0 & 12.1 & 7.5 \\
Ireland & 32.2 & 24.0 & 9.8 & 7.7 \\
France & 25.0 & 23.0 & 10.1 & 10.1 \\
United Kingdom & 27.5 & 16.9 & 7.0 & 10.4 \\
Germany & 44.1 & 39.4 & 18.2 & 12.6 \\
Spain & 71.5 & 37.1 & 17.3 & 25.4 \\
Finland & 60.0 & 64.1 & & 6.3 \\
\hline
\end{tabular}

Source: Herbertsson and Orszag (2000), Blöndahl and Scarpetta (1998) and OECD (1997)

in social security wealth, which in turn is very different from a dollar in asset holdings. Furthermore, Costa reports that the responsiveness of retirement to income has been falling in the last century.

\section{Disability and unemployment benefits}

The importance of disability in explaining changes in labour market participation is controversial. ${ }^{18}$ In the US literature, many researchers have argued that while disability benefits have led to decreased labour market participation, the primary explanation lies elsewhere.

Bound and Waidmann ${ }^{19}$ use data on self-reported disability to conclude that only about a third of the drop in labour force participation in the USA is due to enhanced disability benefits. Bound ${ }^{20}$ also casts doubt on how strong the disincentive effects of disability insurance are by looking at the labour market behaviour of rejected applicants.

The literature on Europe, on the other hand, often finds stronger disincentive effects from disability insurance. This difference may not be surprising, given that disability systems are often more generous in Europe than in the USA.

Morbidity increases with longevity; consequently, the average labour supply of older-age participants might decrease, as a greater proportion of each generation will reach a higher age. This could result in increased pressure on disability and early retirement programmes. Wealth effects and, consequently, early retirement can be created by disability pensions and special unemployment benefits for the old, especially for low-income households. Disability benefits are often substitutes for early retirement pensions as a youth unemployment reduction mechanism. If this is the case, one would potentially find a relationship between non-employment benefits, such as disability and unemployment benefits, and unemployment. However, as Blöndahl and Scarpetta ${ }^{15}$ report that, when comparing disability and unemployment benefits and unemployment, no apparent 
Table 4: Rank correlations between generosity of non-employment benefits and unemployment in the OECD, 1995

\begin{tabular}{lclll}
\hline & $\begin{array}{l}\text { Disability } \\
\text { schemes }\end{array}$ & $\begin{array}{l}\text { Unemployment } \\
\text { schemes }\end{array}$ & $\begin{array}{l}\text { Unemployment } \\
\text { males total }\end{array}$ & $\begin{array}{l}\text { Unemployment } \\
\text { males 55-64 }\end{array}$ \\
\hline Disability schemes & 1.00 & & & \\
Unemployment schemes & 0.29 & 1.00 & 1.00 & \\
Unemployment total & 0.01 & -0.07 & 0.77 & 1.00 \\
Unemployment 55-64 & -0.18 & -0.09 & \\
\hline
\end{tabular}

Source: Blöndhal and Scarpetta (1998), OECD (1997) and author's calculations

relationship is to be seen between the levels of non-employment benefits and unemployment, neither in total nor elderly male unemployment (see Table 3 ).

Table 4 reports the Spearman rank correlations between the variables in Table 3.

Table 4 confirms the findings of Blöndahl and Scarpetta: no significant correlation exists between their generosity index, neither for disability benefits nor for unemployment benefits, and unemployment. But not all researchers have come to this conclusion.

In a recent study, Campolieti ${ }^{21}$ estimates the effect of more generous disability pensions in Canada on labour force participation rates of 45-64 year-old males in a regression analysis. His estimates seem sensitive to model specification. However, under reasonable assumptions Campolieti finds that a 10 per cent increase in disability benefits implies a $0.2-0.9$ per cent decline in the participation rates of older males.

\section{Recessions}

Economic downturns affect early retirement since the probability of becoming unemployed rises during recession. Consequently, people near retirement age are more willing to leave the labour force and go into early retirement. Lower real-wages during recessions can also contribute to early retirement since the opportunity cost of retiring (measured in forgone wages) is lower during recessions. A fall in asset prices during recessions works in the opposite direction, as people might postpone their retirement when private wealth decreases.

\section{DC vs. DB schemes}

Workers in public defined benefit plans may have an incentive to retire earlier than workers in defined contribution plans if the early retirement penalties are too light, as they typically are. The exact effects depend on the type of salary scheme that forms the basis for the contributions and on the age-earning profiles. The theory predicts that in systems with high replacement ratios, workers would be tempted to retire early. But, as is mentioned above, not all empirical studies have been successful in confirming this relationship. This can be explained in part by the fact that, in some countries, workers who retire early are penalised by actuarial adjustments. On the other hand, accrual rates at older ages seem to have a significant impact on the retirement decision.

\section{Taxes}

When the income-tax system is progressive, the difference between the tax on earned income and the tax on income from pensions distorts compensation received in favour of early retirement. Also, if taxes on earned income are higher than taxes on pension 
benefits, an incentive for early retirement is created.

\section{Increased recreation opportunities}

It is a well-established fact that labour supply decisions depend on the preference for leisure, which usually becomes stronger with higher income and advanced age. Consequently, as private wealth increases, the preferences for leisure become an important motivation for leaving the labour force. Not only can a greater number of older workers afford to retire early, it has become more socially acceptable to do so. Costa ${ }^{17}$ reports that elasticity for recreation has declined in the USA since the turn of the century, speculating that this decline was in part driven by an increased demand for leisure fuelled by rising incomes and by the increase in the variety of low-cost leisure-time activities.

\section{Changing age structures}

Because of the broad dissemination of medical knowledge and declining fertility, the industrialised countries are constantly growing older. Increased longevity contributes to a fall in the relative supply of healthy workers. As life expectancy increases, more disabled people will survive to adulthood, and a larger fraction of the population will be disabled. For this reason inactivity will rise with changing age structures.

\section{Transitional effects}

In a society based on farming there is no idle hand. As people grow old they simply contribute less to work on the farm - the children have taken over. This was the case though the history of mankind. However, since the industrial revolution agriculture has constantly become a smaller part of the economy, and 'new' industries do not operate in this way. Therefore, an increased number of people did go into retirement and, as the extended family was dissolved, older farmers moved into towns to make room for their children. This contributed to early retirement, although the effect was probably very small in recent decades.

\section{Social effects}

For centuries, life was more or less based on providing for oneself and one's family. During the last century, however, the State has played a larger role in supporting families that, for some reason, could not provide for themselves. After World War II people also saw the advent of the welfare state. Social contracts such as pay-as-you-go systems were made, and safety nets were strengthened. It is possible that during this transition period it became more socially acceptable to collect benefits and accept early retirement. Thus the great fall in male participation rates observed in the $70 \mathrm{~s}$ and the 80s might simply constitute a tipping point in social values. ${ }^{22}$

\section{Labour demand}

This paper has considered various explanations for early retirement that can be traced to the supply side of the labour market. Most of the explanations revolve around planned voluntary retirement decisions. But early retirement can also be traced to the demand side of the market and involuntary retirement, as the survey reported in Table 1 shows. A worker who enters the labour market at a young age initially has a high probability of entering the unemployment pool, but the probability falls as the worker gets older, takes on family responsibilities, and loses parental support. This effect is more pronounced as the number of children increases and 
the income of the spouse decreases. However, with the passage of time, this effect is reversed as the children leave home and accumulated savings and pension rights create a nice cushion in case of dismissal or voluntary quitting. This development eventually leads to retirement from the labour market. So a typical worker begins and ends his labour-market participation by depending on non-wage income in different forms.

\section{Age structure}

Job security rises with increased tenure and hence, ceteris paribus, with age. Herbertsson, Phelps, and Zoega ${ }^{23}$ report that the unemployment rate of the young, 15-24-year-olds, was higher than that of the older generations in all of the OECD economies in 1998, except in Germany, where unemployment of the age group $55+$ is higher than in the youngest age groups. As Lazear points out, if firms offer wages commensurate with seniority rather than marginal product, they might encourage older workers to retire early or even lay them off before younger workers. Since it is more difficult to dismiss an old worker, the sensitivity of employment to shocks could be a decreasing function of the size of the older cohorts in an economy. The age structure and the institutional framework may interact in such way that the protection against dismissal increases with age. However, firms may opt for early retirement instead of dismissals; thus corporate restructuring would show up in lower labour-force participation instead of unemployment. Furthermore, a transitory shock is more likely to lead to the dismissal of an older worker because of his shorter expected post-depression tenure. Thus, the level of labour hoarding may be smaller for older workers due to their shorter remaining work life. This would make the sensitivity to shocks greater.

Older workers may find it more difficult to find another job, as their remaining tenure is shorter. They may also be more resistant to real wage moderation because their accumulated wealth reduces their dependence on employment. This raises the possibility that real-wage cuts are less likely, as the proportion of older workers is higher. They are therefore more likely to become unemployed for the long term. As a result, the higher the proportion of older workers in the labour force, the more likely a transitory shock is to have a persistent effect on employment and push people into early retirement.

\section{Transitional effects}

Older workers who started their career in a growing industry might find themselves in a declining industry as they near the age of retirement. If older workers are laid off, they might find themselves competing with better-educated and younger workers for jobs in new and growing industries. As the average unemployment spell has risen for all workers, this might encourage older workers to go into early retirement rather than continue their search for new jobs. Many countries have reacted to this problem by designing programmes that transfer older workers from long-term unemployment into retirement.

A related issue, which arises in the context of private occupational defined benefit schemes, is that older workers can be quite expensive in terms of their pension costs. Therefore, early retirements are a particularly effective manner of cutting business costs for firms. Firms do not bear the external costs to the public system of any extra benefit costs and lost tax revenue to the government associated with early retirement, thereby compounding the 
early retirement problem. As noted in Orszag and Snower, ${ }^{25}$ because firms do not internalise the costs of forcing early retirement, more people retire early leading to higher costs for the state than if firms were forced to bear the cost burden themselves.

\section{Conclusions}

The withdrawal of older workers from the labour force creates a variety of economic challenges, including an increase in unused production capacity. Costs due to early retirement measured in terms of forgone output averaged 6.3 per cent of potential gross domestic product in the OECD in 1998. The costs, which vary greatly from country to country, are highest in Hungary (15.9 per cent of potential output) and lowest in Iceland (0.5 per cent). These differences are important for policy makers to the extent that their causes are rooted in economic policy and structure rather than in cultural and environmental factors. In light of the costs, this paper attempts to summarise and discuss alternative theories on why people retire early, in order to understand better the roots of the problem.

\section{Acknowledgment}

The author would like to thank Ásgeir Jónsson and J. Michael Orszag for comments.

\section{References}

1 UK Cabinet Office (2000) 'Winning the Generation Game', April, Performance and Innovation Unit, London.

2 Herbertsson, T. T., and Orszag, J. M. (2001) 'The Cost of Early Retirement in the OECD', work in progress.

3 Disney, R. and Whitehouse, E. R. (1999) 'Pension Plans and Retirement Incentives', SP Discussion Paper No. 9924, World Bank, August.

4 The decline in labour force participation has reversed a bit in the past few years. However, as Costa (1999) points out, this is not unprecedented and is not necessarily part of a long-run trend.
Costa, D. L. (1999) 'Has the Trend Towards Early Retirement Reversed?', First Annual Joint Conference for the Retirement Research Consortium, Reprint: 99.

5 Gruber, J. and Wise, D. (1999) 'Social Security and Retirement Around the World', NBER Volume, University of Chicago Press, Chicago.

7 Boskin, M. J. (1977) 'Social Security and Retirement Decisions', Economic Inquiry, 15, No. 1, pp. 1-25.

8 Quinn, J. F., Burkhauser, R. V. and Myers, D. A. (1990) 'Passing the Torch: The Influence of Economic Incentives on Work and Retirement', Upjohn Institute for Employment Research.

9 Stock, J and Wise, D. (1990) 'Pensions, the Option Value of Work and Retirement', Econometrica 58, pp. 1151-1180.

10 Fields, G. S. and Mitchell, O. (1984) 'The Effects of Social Security Reforms on Retirement Ages and Retirement Incomes', Journal of Public Economics, Winter.

11 Borsch-Supan, A. (1992) 'Population Aging, Social Security Design, and Early Retirement', Journal of Institutional and Theoretical Economics, 148, pp. 533-557.

12 Meghir, C. H. D. and Whitehouse E. R. (1996) 'The Evolution of Wages in the UK: Evidence from Micro Data' Journal of Labour Economics.

13 OECD (1995a) 'The Labour Market and Older Workers', OECD, Paris.

14 OECD (1995b) 'The Transition from Work to Retirement', Social Policy Studies, OECD, Paris.

15 Blöndahl, S. and Scarpetta, S. (1998) 'The Retirement Decision in the OECD Countries', Economics Department Working Paper No. 202, OECD, Paris.

16 Johnson, R. (2000) 'The Effect of Old-age Insurance on Male Retirement: Evidence from Historical Cross-country Data, Federal Reserve Bank of Kansas City, Research Working Paper No. 00-09, December.

17 Costa, D. L. (1998) 'The Evolution of Retirement: An American History', 1980-1990, The University of Chicago Press, Chicago.

18 Aarts and DeJong examine broad issues of disability within a multipillar framework. Aarts, L. and DeJong, P. (1999) 'Disability within a Multipillar Framework', paper presented at World Bank Conference: New Ideas About Old Age Security, September 14-15, Washington DC.

19 Bound, J. and Waidmann, T. (1992) 'Disability Transfers, Self-Reported Health, and the Labour Force Attachment of Older Men: Evidence from the Historical Record', Quarterly Journal of Economics, 107, No. 4, pp. 1393-1419.

20 Bound, J. (1989) 'The Health and Earnings of Rejected Disability Insurance Applicants', American Economic Review, 79, No. 3, pp. 482-503.

21 Campolieti, M. (2001) 'The Canada/Quebec Pension Plan Disability Program and the Labour Force Participation of Older Men', Economics Letters, 70, pp. 421-426. 
21 OECD (1997) 'Labour Force Statistics' 1976-1996, OECD, Paris.

22 See Gladwell for a discussion on tipping points. Gladwell, M. (2000) 'The Tipping Point: How Little Things Can Make a Big Difference', Little Brown \& Company.

23 Herbertsson, T. T., Phelps, E. and Zoega, G. (2001), 'Age Distribution and Unemployment,' work in progress.

24 Lazear, E. P. (1979) 'Why is There Mandatory Retirement?' Journal of Political Economy, 87, No. 6, pp. 1261-1284.

25 Orszag, J. M. and Snower, D. (1999) 'Pensions Taxes versus Early Retirement Rights', Working Paper 1999-22, http://www.pensions-research. org/papers, November. 